\title{
EFEKTIVITAS KINERJA PEGAWAI DALAM PELAYANAN PEMBUATAN E-KTP PADA DINAS KEPENDUDUKAN DAN CATATAN SIPIL KABUPATEN POLEWALI MANDAR
}

\author{
Nur Fitrah $^{2}$, Karmila ${ }^{3}$ \\ ${ }^{2}$ Prodi Ilmu Pemerintahan, Fakultas Ilmu Sosial dan Ilmu Pemerintahan \\ Universitas Al Asyariah Mandar \\ Email: nurfitrah110591@gmail.com \\ 3Prodi Ilmu Pemerintahan, Fakultas Ilmu Sosial dan Ilmu Pemerintahan \\ Universitas Al Asyariah Mandar \\ Email: Karmila05041998@gmail.com
}

\begin{abstract}
This study aims to determine the effectiveness of employee performance towards the service of making E-KTP at the Department of Population and Civil Registry of Polewali Mandar Regency, which is more effective in carrying out service duties at the office and find out what are the inhibiting factors of the service. There are also benefits to the research. Namely, it can provide useful information to all walks of life and provide input for the community so that they can motivate employees when carrying out their duties given by the leader. Then it can be determined the results obtained in carrying out public services Polewali Mandar District Government (DISDUKCAPIL), has not been effective in carrying out its service duties that have been measured from two variables that produce an average value recapitulation of the effectiveness of employee performance is 61.0. The average of E-KTP Services was 38.1, with 65 respondents divided into 30 employees and 35 communities. The inhibiting factor is not an effective service in the current situation pandemic, but the employee has made various efforts more effective than before.
\end{abstract}

\section{ABSTRAK}

Penelitian ini bertujuan untuk mengetahui efektivitas kinerja pegawai terhadap pelayanan pembuatan E-KTP pada Dinas Kependudukan dan Catatan Sipil Kabupaten Polewali Mandar yang lebih efektif dalam melaksanakan tugas pelayanan pada kantor dan mengetahui apa saja yang menjadi faktor penghambat dari pelayanan tersebut.Adapula manfaat dari penelitian tersebut yaitu dapat memberikan informasi yang berguna pada semua kalangan dan memberikan masukan bagi masyarakat agar dapat memotivasi terhadap pegawai saat menjalankan tugasnya yang telah diberikan oleh pemimpin. Maka dapat ditentukan hasil yang diperoleh dalam melaksanakan pelayanan publik Pemerintah Kabupaten Polewali 
Mandar pada (DISDUKCAPIL), belum efektif dalam menjalakan tugas pelayanannya yang telah di ukur dari dua variabel yang menghasilkan rekapitulasi nila rata-rata terhadap efektivitas kinerja pegawai adalah 61,0 dan nilai rata-rata terhadap Pelayanan E-KTP adalah 38,1 dengan jumlah 65 responden yang terbagi dari 30 pegawai dan 35 masyarakat. Sehingga faktor penghambat tidak efektifnya suatu pelayanan pada situasi pademi yang terjadi saat ini, akan tetapi pegawai tersebut sudah melakukan berbagai upaya yang lebih efektif dari sebelumnya.

Kata Kunci: Efektivitas, Kinerja, Pegawai

\section{PENDAHULUAN}

Kinerja organisasi menurut Moeheriono $(2009 ; 60)$ yaitu suatu proses berlangsungnya suatu kegiatan untuk yang telah dicapai kegiatan yang harus dilakukan pengecekkan. Penilaian dan review atau peninjauan terhadap kinerja sumber daya manusia. Melalui monitering dilakukan pengukuruan dan penilaian kinerja secara periodik untuk mengetahui pencapaian kemajuan kinerja yang dilakukan prediksi yang memungkinkan terjadi pelaksanaan terhadap rencana yang dapat mengganggu suatu tujuan terhadap capaian.

Efektivitas merupakan suatu tingkatan keberhasilan yang dicapai seseorang dengan melakukan tugas-tugas yang dibebankan kepadanya yang didasarkan pada kecakapan pengetahuan dan kesungguhan serta waktu, sedangkan kinerja adalah hasil kerja yang dicapai oleh seseorang atau sekelompok orang dalam suatu organisasi dalam rangka mencapai tujuan (Ismail Nawawi, 2015:18).

Peningkatan kualitas sumber daya pegawai menjadi sangat penting dan perlu dilakukan secara terencana, terarah dan berkesinambungan dalam rangka meningkatkan kemampuan dan profesionalisme. Sasaran dari pengembangan kualitas sumber daya pegawai adalah untuk meningkatkan kinerja operasional pegawai dalam melaksanakan tugas-tugas pemerintahan.

Kinerja pegawai merupakan salah satu upaya dalam menentukan keberhasilan pencapaian tujuan dikarenakan organisasi merupakan faktor yang dapat mewujudkan efektivitas dan efesiensi dalam pelaksanaan tugas dan fungsi organisasi. Hal yang terjadi pada kinerja pegawai dalam pelayanan KTP pada Dinas Kependudukan dan Catatan Sipil Kabupaten Polewali Mandar masih lambat dan kurang efektif yaitu kurangnya petugas/pegawai yang memiliki pengetahuan atau kemampuan di bidangnya dimana kualitas organisasi sangat tergantung dari sejauh mana sumberdaya manusia atau pegawainya dapat menyelesaikan tugas dan kegiatannya seefektif mungkin. 
Dalam hal pelayanan, dapat dikatakan berkualitas apabila hal tersebut dapat diselenggarakan sesuai pada waktu yang telah ditentukan.

Berdasarkan hasil observasi di Dinas Kependudukan dan Catatan Sipil Kabupaten Polewali Mandar terlihat bahwa terdapat beberapa masalah keluhan proses pembuatan e-KTP bahwa kendala tersebut terdapat pada Blangko dari Pemerintah Pusat.

\section{METODE PENELITIAN}

Penelitian ini menggunakan jenis penelitian deskriptif dengan pendekatan kuantitatif. Data kuantitatif menurut Sugiyono (2013:14) merupakan data yang berbentuk angka yang diangkakan. Pendekatan kuantitatif adalah pencarian data/informasi dari realitas permasalahan yang ada dengan mengacu pada pembuktian konsep/teori yang digunakan. Dalam hal ini untuk memberikan gambaran tentang Akuntabilitas Kinerja Pelayanan e-KTP di Dinas Kependudukan dan Catatan Sipil Kabupaten Polewali Mandar dengan tujuan untuk mengumpulkan sejumlah data dan informasi dengan cara pembagian kuesioner kepada responden yang bersangkutan. Tipe penelitian ini adalah Fenomenologi dengan didukung data kuantitatif dimana peneliti berusaha untuk mengungkapkan suatu fakta atau realita mengenai efektivitas kinerja pegawai dalam pelayanan pembuatan E-KTP pada Dinas Kependudukan dan Catatan Sipil (DISDUKCAPIL) Kabupaten Polewali Mandar.

Penepatan lokasi penelitian bertempat di Polewali Mandar pada Dinas Kependudukan dan Catatan Sipil (DISDUKCAPIL) Kabupaten Polewali Mandar. Adapun alasan memilih lokasi penelitian tersebut karena masih banyak keluhan masyarakat terhadap kurang optimalnya pelayanan pada masyarakat pengguna layanan Pembuatan e-KTP.

Beberapa responden dalam penelitian ini terdiri dari Kepala Bidang, Kepala Dinas, para Pegawai yang berjumlah 30 Orang, dan masyarakat berjumlah 35 orang. Jadi jumlah responden yaitu 65 orang.

Tabel 1

Responden Penelitian

\begin{tabular}{|c|c|c|}
\hline No & Responden & Jumlah \\
\hline 1 & Pegawai & 30 \\
\hline 2 & Masyarakat & 35 \\
\hline & Keseluruhan & $\mathbf{6 5}$ \\
\hline
\end{tabular}


Menurut Suharsimi Arikunto (2013:173) "Prosedur Penelitian"Populasi adalah keselurahan dari subjek peneliti. Jika setiap manusia memberikan suatu data, maka ukuran atau banyaknya populasi akan sama dengan banyaknya manusia. Berkenaan dengan penelitian ini maka yang menjadi populasi adalah seluruh pegawai dan staf dari segala bidang yang berjumlah 30 orang dengan jumlah keseluruhan pegawai ada 114 orang di dalam sebuah instansi dan 35 masyarakat.

Menurut Suharsimi Arikunto (2012:104) "Prosedur Penelitian "jika jumlah populasinya kurang dari 100 orang, maka jumlah sampelnya diambil secara keseluruhan, tetapi jika populasinya lebih besar dari 100 orang maka bisa diambil $10-15 \%$ atau $20-25 \%$ dari jumlah populasinya. Berdasarkan penelitian ini karena jumlah populasinya tidak lebih besar dari 100 orang responden maka penulis mengambil $100 \%$ jumlah populasi yang ada pada Badan Penelitian Pengembangan Dan Perencanaan yaitu sebanyak 65 orang responden, maka sampel yang digunakan yaitu sampel jenuh.

Variabel yang dikaji dalam penelitian ini adalah Efektivitas sebagai variabel bebas (X1), Pelayanan (X2) dan e-KTP sebagai variabel terikat (Y).Variabel bebas (Independent) adalah variabel yang tidak terikat, tidak dipengaruhi bahkan mempengaruhi atau menjadi penyebab perubahan dan timbulnya variabel lain yaitu variabel terikat.Variabel Terikat (Dependen) adalah faktor-faktor yang diamati dan diukur oleh peneliti dalam sebuah penelitian untuk menentukan ada tidaknya pengaruh dari variabel bebas.

\section{a. Efektivitas}

Efektivitas meskipun sering diucapkan,tetapi sering pengertiannya mempunyai makna yang berbeda. Suatu upaya untuk mendefinisikan yang umum dan sering digunakan adalah bertumpu pada pendekatan efektivitas dari segi optimasi tujuan,yakni kemampuan organisasi memanfaatkan sumber daya untuk mencapai tujuan yang telah ditetapkan. pendefinisian yang sederhana tersebut menimbulkan kebingungan apabila kita hendak mengoperasikan konsep tujuan. Oleh karena itu, definisi yang bertumpu pada optimasi tujuan haruslah diberi makna sebagai tujuan yang diukur menurut konsep organisasi, yaitu ukuran mengenai seberapa jauh suatu organisasi mencapai tujuan yang hendak capai. Terdapat beberapa idikator penilaian efektivitas yaitu Kemampuan menyesuaikan diri,Prestasi kerja, Kepuasan kerja.

b. Pelayanan

Menurut Hardiyansyah (2011:42) pelayanan publik mempunyai ciri publik accountability, dimana setiap warga Negara mempunyai hak untuk mengevaluasi kualitas pelayanan yang mereka terima. Untuk menilai kualitas suatu pelayanan akan mengalami kesulitasn jika tidak mempertimbangkan 
peran masyarakat sebagai penerima pelayanan dan aparat pelaksana pelayanan itu. Sedangkan dasar untuk menilai seuatu kualitas pelayanan selalu berubah dan berbeda. Terdapat beberapa indikator penilaian kualitas pelayanan publik yaitu penampilan petugas atau aparatur dalam melayani masyarakat, kenyamanan tempat melakukan pelayanan, kemudahan dalam proses pelayanan, kedisiplinan petugas/aparatur dalam melakukan pelayanan.

\section{c. E-KTP}

E-KTP adalah Kartu Tanda Penduduk yang dibuat secara Elektronik dalam artian baik dari segi fisik maupun cara penggunaanya yang brfungsi secara komputerisasi, sehingga diperlukan perlakuan khusus dalam pelayanannya terlebih pada kondisi masyarakat dengan adanya program eKTP. Hal ini sangat penting untuk diperhatikan karena mengingat e-KTP yaitu identitas yang wajib dimiliki oleh setiap warga Negara seperti yang tercantum dalam UU No.23 Tahun 2006 tentang Administrasi Kependudukan pada BAB V Pendaftaran Kependudukan pasal 13 (ayat) 1 yang menyatakan bahwa :"Setiap penduduk wajib memiliki NIK". NIK yaitu merupakan Nomor Kependudukan yang ada pada e-KTP , Nik inilah yang nantinya akan dijadikan dasar dalam membuat berbagai jenis dokumen Identintitas (SIM, Paspor dsb

Instrumen angket dalam penelitian ini disusun secara tertutup dengan skala likert. Menurut Ridwan (2011:20) skala likert digunakan untuk mengukur sikap dan pendapat seseorang atau sekelompok orang tentang kejadian/gejala sosial. Variabel yang diukur dijabarkan menjadi indikator variabel melalui penggunaan skala likert. Indikator tersebut dijadikan sebagai acuan dalam penyusunan item instrumen berupa pernyataan yang perlu dijawab oleh responden.

Angket yang digunakan dalam penelitian ini adalah angket tertutup dengan 5 alternatif jawaban, yaitu sangat setuju (SS), setuju (S), Netral (N) tidak setuju (TS) dan sangat tidak setuju (STS). Menurut Ridwan (2011:100) Angket tertutup adalah angket yang disajikan dalam bentuk sedemikian rupa sehingga responden diminta untuk memilih satu jawaban yang sesuai dengan karakteristik dirinya dengan cara memberikan tanda silang atau tanda check list.

Untuk mendeskripsikan data pada setiap variabel penelitian dilakukan dengan menyususn tabel distribusi frekuensi untuk mengetahui apakah tingkat perolehan nilai (skor) variabel penelitian masuk dalam kategori : sangat setuju, setuju, kurang setuju, sangat tidak setuju. Untuk skor rata-rata maka jumlah jawaban kuesioner dibagi jumlah penyataan dikalikan jumlah responden. Untuk lebih jelas berikut rumusnya : 


$$
\text { Skor Rata-rata }=\frac{\sum \text { Jawaban Kuesioner }}{\sum \text { Pernyataan } \times \sum \text { Responden }}
$$

Setelah diketahui skor rata-rata maka hasil tersebut dimasukan ke dalam garis kontinum dengan kecenderungan jawaban responden akan didasarkan pada nilai rata-rata skor yang selanjutnya akan dikatagorikan pada rentang skor sebagai berikut :

$$
r=\frac{S T-S R}{K}
$$

Dimana :

$$
\begin{aligned}
& \mathrm{R}=\text { Rentang/skala } \\
& \mathrm{ST}=\text { Skor jawaban tertinggi } \\
& \mathrm{SR}=\text { skor jawaban terendah } \\
& \mathrm{K}=\text { Kategori }
\end{aligned}
$$

\section{HASIL DAN PEMBAHASAN}

Data hasil penelitian terdiri dari dua variabel bebas yaitu Efektifitas Kinerja Pegawai (X1) dan Pelayanan Masyarakat (X2) dan satu variabel terikat yaitu E-KTP (Y). untuk mendeskripsikan dan menguji pengaruh variabel bebas dan variabel terikat dalam penelitian ini, maka pada bagian ini akan disajikan deskripsi data dari masing-masing variabel berdasarkan data yang diperoleh dilapangan.

Berdasarkan hasil dari judul "Efektivitas Kinerja Pegawai Dalam Pelayanan Pembuatan E-KTP pada Dinas Kependudukan dan Catatan Sipil (DISDUKCAPIL) Kabupaten Polewali Mandar dikatakan efektif apabila dapat dilihat dari 3 indikator. variabel efetivitas $(\mathrm{X} 1)$ dari tabel dibawah ada 65 responden yaitu prestasi kerja dengan persentasi kerja setuju $48 \%$ tidak efektif. Sementara kepuasan kerja mempunyai persentasi setuju $62 \%$ efektif. Menyesuaikan diri dengan persentasi setuju $46 \%$ tidak efektif.perencanaan yang matang persentasi setuju 54\% efektif. Kemampuan menyesuaikan diri dengan persentasi setuju $46 \%$ efektif. Dari penjelasan diatas bahwa yang tidak efektifyaitu prestasi kerja, menyesuaikan diri, kemampuan menyesuaikan diri , dan kepuasan kerja.

Variabel Pelayanan Masyarakat (X2) hasil yang diperoleh dibagikan melalui kuesioner oleh responden dengan berjumlah 65 orang serta 3 indikator yaitu Kenyamanan Tempat dengan persentasi setuju 38\% tidak efektif. Kedisiplinan persentasi setuju 52\% efektif. Evaluasi dengan persentasi setuju $52 \%$ efektif. Penampilan Petugas dengan persentasi setuju 48\% tidak efektif. 
Pembagian tugas dengan persentasi setuju 50\% efektif. Penilaian dengan persentasi setuju 54\% efektif. Dapat kita simpulkan ada beberpa indikator yang tidak efektif dan efektif.

Adapun variabel E-KTP (Y) Hasil yang diperoleh dilapangan melalui kuesioner oleh responden dengan berjumlah 65 orang serta indikator yaitu indikator Kuantitas dengan persentasi setuju 42\% tidak efektif. Indikator Kualitas dengan persentasi setuju 50\% efektif. Indikator Ketetapan Waktu dengan persentasi setuju 56\% efktif. Indikator Efektifitas dengan persentasi setuju $52 \%$ efektif. Indikator Kemandirian dengan persentasi setuju $62 \%$ efektif. Indikator SDM dengan persentasi setuju 44\% efektif. Indikator Fasilitas dengan persentasi setuju 54\% efektif. Indikator Kerja Sama Tim dengan persentasi setuju $46 \%$ efektif. Sehingga dari penejelasan di atas masi masi ada bebrapa indikator yang tidak efektif mulai dari Kuantitas, Kehadiran, Kerja Sama Tim, SDM, dan Disiplin Ilmu.

Capaian kinerja pada ketersediaan data base kependudukan menunjukkan bahwa . pada tahun 20018 mencapai $40 \%$ hingga akhir tahun 2019 telah mencapai $100 \%$. Ini menunjukkan bahwa selama lima tahun data lahir mati pindah dan datang masuk dalam data base kependudukan. E-KTP mulai dilaksanakan pada tahun 2018 dengan capaian $8.6 \%$ sampai pada tahun 2019 E-KTP mencapai 91.2\%.

Tabel 2

Rekapitulasi Nilai Rata-rata dari Variabel Penelitian

\begin{tabular}{|c|c|c|}
\hline No & Uraian & Nilai \\
\hline \multirow[t]{6}{*}{1.} & Efektivitas Kinerja Pegawai & \\
\hline & a. Kemampuan Menyesuaikan Diri & 54 \\
\hline & b. Prestasi Kerja & 64 \\
\hline & c. Kepuasan Kerja & 66 \\
\hline & d. Ketetapan Waktu & 60 \\
\hline & Nilai rata-rata & 61,0 \\
\hline \multirow[t]{5}{*}{2.} & Pelayanan E-KTP & \\
\hline & a. Fasilitas & 66 \\
\hline & b. Kenyamanan Tempat & 64 \\
\hline & c. Kedisiplinan Pegawai & 114 \\
\hline & Nilai rata-rata & 38,1 \\
\hline
\end{tabular}

Sumber Data : Diperoleh dari Data Hasil Penelitian, Mei 2020

Data tabel penelitian tersebut dengan hasil pembagian kuisioner kepada responden yang berjumlah 65 orang dinyatakan bahwa uraian dari tabel di atas terdapat 2 variabel dan berjumlah keseluruhan ada 7 indikator. Maka 
dapat dinyatakan variabel efektifitas kinerja pegawai terdapat 61,0 persentase dari hasil pembagian kuisioner, sedangkan variabel pelayanan pembuatan eKTP terdapat nilai rata-rata 38,1 persentase dari hasil tanggapan respon. Jadi dapat ditentukan masyarakat belum puas atas pelayanan pembuatan e-KTP pada Dinas Kependudukan dan Catatan Sipil Kabupaten Polewali Mandar.

Dari faktor pelayanan publik yang dilihat dan diamati oleh penulis di bahwa hal yang utama menghambat proses pelaynan E-KTP, yang terjadi di Dinas Kependudukan Dan Catatan Sipil Kabupten Polewali Mandar, itu bukan hanya dari pihak internal pegawai sendiri sebagi faktor penunjang pelayanan keinerja dalam hal ini yang dimaksud adalah menentukan seberapa cepatkah proses pelayanan diberikan pegawai pada masyarakat akan tetapi, fasilaitas dalam hal ini peralatan penunjang pembuatan E-KTP, yang tersedia di Dinas Kependudukan Dan Catatan Sipil Kabupaten Polewali Mandar juga sangat berpengaruh. Minimnya fasilitas yang menyebabkan turunya kinerja pegawai dalam melakukan pelayanan E-KTP dan berindikasi pada profesonalisme pegawai Dinas Kependudukan Dan Catatan Sispil dalam melakukan pelayanan E-KTP di Kabupaten Polewali Mandar.

Hasil penelitian tersebut maka peneliti dapat memberikan gambaran dan hasil penilaian yang berjudul efektivitas kinerja pegawai terhadap pelayanan pembuatan E-KTP pada kantor Dinas Kependudukan dan Catatan Sipil Kabupaten Polewali Mandar, dengan ini peneliti dapat menguraikan pembahasan tujuan peneliti dapat di uraikan dari data yang diperoleh atau informasi yang telah di dapatkan dan membagikan kuisioner yang berjumlah 65 responden dengan 30 pernyataan mengenai efektivitas kinerja pegawai yang dapat ditanggapi oleh responden, sehingga peneliti dapat menganalisi kinerja tersebut.

Penelitian ini termasuk dengan penelitian eksperimen karena penelitian ini bertujuan mengetahui sebab akibat serta berapa besar pengaruh tersebut. Hasil penelitian yang terjadi dilapangan dengan menganalisis data kuisioner yang di bagikan kepada responden ialah 65 orang menunjukkan bahwa variabel Efektivitas Kinerja Pegawai (X1) dalam suatu instansi yang dimana berjalan dengan efektifnya suatu kinerja melalui hasil yang ingin dicapai. Sehingga menurut Siagian (2014:28) menyatakan, "Efektivitas kerja sebagai penyelesaian pekerjaan tepat pada waktunya yang telah diterapkan, yang artinya apakah pelaksanaan suatu tugas dinilai baik atau tidak tergantung bilamana tugas itu dilaksanakan, dan tidak menjawab bagaimana melaksanakannya, sehingga mencapai kinerja yang efektif".

Salah satu teori yang menyatakan pelayanan publik yakni Sinambela (2011:5) berpendapat bahwa pelayanan publik adalah pemenuhan keinginan dan kebutuhan masyarakat oleh penyelenggara negara. Negara didirikan oleh 
publik (masyarakat) tentu saja dengan tujuan agar dapat meningkatkan kesejahteraan masyarakat. Pada hakikatnya Negara dalam hal ini pemerintah (birokrat) haruslah dapat memenuhi kebutuhan masyarakat. Kebutuhan dalam hal ini bukanlah kebutuhan secara individual, akan tetapi berbagai kebutuhan yang sesungguhnya diharapkan oleh masyarakat, misalnya kebutuhan akan kesehataan, pendidikan, dan lain lain.

Variabel (Y) E-KTP adalah Kartu Tanda Penduduk yang dibuat secara Elektronik dalam artian baik dari segi fisik maupun cara penggunaanya yang brfungsi secara komputerisasi, sehingga diperlukan perlakuan khusus dalam pelayanannya terlebih pada kondisi masyarakat dengan adanya program eKTP. Hal ini sangat penting untuk diperhatikan karena mengingat e-KTP yaitu identitas yang wajib dimiliki oleh setiap warga Negara seperti yang tercantum dalam UU No.23 Tahun 2006 tentang Administrasi Kependudukan pada BAB V Pendaftaran Kependudukan pasal 13 (ayat) 1 yang menyatakan bahwa"Setiap penduduk wajib memiliki NIK". NIK yaitu merupakan Nomor Kependudukan yang ada pada e-KTP , Nik inilah yang nantinya akan dijadikan dasar dalam membuat berbagai jenis dokumen Identintitas (SIM, Paspor dsb).

Kewenangan dari Pemerintah Kecamatan Polewali dalam hal pelayanan pembuatan e-KTP yakni Camat dalam perspektif ini memiliki posisi penting dan fungsi yang sangat strategis, sekaligus kejelian dalam memahami kondisi daerahnya, bagi perkembangan munculnya kebijakan pemerintah yang lebih tinggi yaitu pemerintah Kabupaten/Kota, dan peran penting Camat lainnya merupakan kemampuannya dalam memenuhui kebutuhan masyarakatnya yang ada pada daerahnya.

Menurut Richard (2014) untuk mengukur efektivitas kerja adalah kemampuan menyesuaikan diri, prestasi kerja, kepuasan kerja, faktor pendukung dan faktor penghambat dalam efektivitas guna mencapai pelayanan kepada masyarakat.

Dapat disimpulkan dari sebuah indikator melalui responden yang berjumlah 65 orang bahwa pemimpin dan bawahan menunjukkan bahwa Kinerja aparatur di Dinas Kependudukan dan Catatan Sipil Kabupaten Polewali Mandar, dalam hal melakukan pelayanan publik pada bidang pembuatan Kartu Tanda Penduduk (E-KTP) dapat diketahui dari hasil penelitian ternyata sebagian besar dari masyarakat setempat belum puas dengan pelayanan yang telah diberikan oleh pihak instansi atau kantor belum bisa menunjang pelakasanaan pelayanan publik khususnya pada pelayanan pembuatan Kartu Tanda Penduduk (E-KTP), yang efektif dan efisien sesuai dengan harapan dari Masyarakat. 
Pegawai pada Dinas Kependudukan dan Catatan Sipil Kabupaten Polewali Mandar proses pelayanan publik dan khususnya pada pembuatan Kartu Tanda Penduduk Elektronik (E-KTP) diharapkan sumber daya manusia sebagai pemberi pelayanan harus benar-benar dan berkopenten dalam bidangnya sehingga mampu memberdayakan fasilitas peralatan pendukung pada proses pelayanan agar dapat terwujudnya sebuah pelayanan yang baik dan cepat sesuai dengan harapan masyarakat. Kemudian fasilitas dan peralatan sebagai penunjang pembuatan Kartu Tanda Penduduk Elektronik (E=KTP) harus ditambah agar dapat memenuhi kebutuhan tersebut.

\section{KESIMPULAN}

Kinerja aparatur di Dinas Kependudukan dan Catatan Sipil Kabupaten Polewali Mandar, dalam hal melakukan pelayanan publik pada bidang pembuatan Kartu Tanda Penduduk (E-KTP). penelitian tersebut dengan hasil pembagian kuisioner kepada responden yang berjumlah 65 orang dinyatakan bahwa terdapat 2 variabel dan berjumlah keseluruhan ada 7 indikator. Maka dapat dinyatakan variabel efektivitas kinerja pegawai terdapat 61,0 persentase dari hasil pembagian kuisioner, sedangkan variabel pelayanan pembuatan eKTP terdapat nilai rata-rata 38,1 persentase dari hasil tanggapan responden maka variabel yang memiliki nilai rata-rata tertinggi yaitu efektivitas kinerja pegawai. Jadi dapat ditentukan masyarakat belum puas dalam pelayanan pembuatan e-KTP) yang efektif dan efisien sesuai dengan harapan dari Masyarakat.

Faktor minimnya fasilitas peralatan penunjang pekerjaan dari pegawai sehingga membuat proses pelayanan menjadi lambat, seperti ketika masyarakat datang membuat (e-KTP), sering terlihat antrian kemudian memerlukan waktu yang cukup lama untuk dapat melakukan percetakan eKTP sehingga membuat masyarakat tidak puas terhadap pelayanan yang diberikan oleh pihak pegawai pada kantor tersebut.

\section{SARAN}

Atasan atau pemimpin seharusnya bisa memberikan arahan kepada pegawai terkait dengan pelayanan yang diberikan oleh masyarakat. Memberikan evaluasi setiap kegiatan yang dilakukan oleh pegawai agar dapat terciptanya sebuah pelayanan publik yang efektif. Pelayanan yang ramah,sopan,adil yang membeda-bedakan masyarakat. Harus berpedoman pada prosedur kerja yang telah ditetapkan. Mampu memberdayakan fasilitas peralatan pendukung pada proses pelayanan sehingga dapat terwujudnya sebuah pelayanan yang baik dan cepat sesuai dengan harapan masyarakat. 


\section{DAFTAR PUSTAKA}

\section{Buku-Buku}

Ahmad Al Furqon 2018, Kualitas Pelayanan Pegawai Dalam Pembuatan EKTP di Dinas Kependudukan dan Catatan Sipil Kabupaten Merangin

Alfirah Januarsi(2018), Akuntabilitas Kinerja Pelayanan e-KTP di Dinas Kependudukan dan Catatan Sipil Kabupaten Maros Makassar

Ahmad, Faizurah. 2014. Efektivitas Kerja Pegawai Dinas Sosial Prov.Sul-Sel. Skripsi Fakultas Ilmu Sosial Dan Ilmu Politik Jurusan Ilmu Administrasi Program Studi Administrasi Negara. Universitas Hasanuddin (Skripsi)

Ali, Nur Sulhana. 2018. Efektivitas Kinerja Pegawai Pada Kantor Badan Perencanaan Pembangunan Daerah (BAPPEDA) Kota Makassar. (Skripsi)

Arikunto, Suharsimi.2012-2013. Prosedur Penelitian: Suatu Pendekatan Praktik. Jakarta: Rineka Cipata

Abdullah, Vicky Ridwan. (2012). Pengertian Penelitian Deskriptif. Medan: Sofmedia.

Dessler, Gary, 2015. Manajemen Sumber Daya manusia, Jakarta: Salemba Empat

Endang Sulistyaningsih, \& Yudo Swasono Pengembangan Sumber Daya Manusia, Jakarta : Cv. Izufa Gempita, 1993.

Henriki ,Efektivitas Pelayanan Pembuatan E-KTP di Kecamatan Kerumutan Kabupaten Pelalawan 2017 (skripsi)

Hardiansyah, 2011 Kualitas Pelayanan Publik : Konsep, Dimensi, Indikator dan Implementasinya. Yogyakarta : Gava Media.

Ibrahim, Amin. 2008. Teori dan Konsep Pelayanan Publik Serta Implementasinya. Jakarta: Mandar Maju

Moenir, H.A.S, 2014 Manajemen Pelayanan Umum Di Indonesia, Jakarta : Bumi Aksara.

Mahmudi, (2005). Manajemen Kinerja Sektor Publik. Yogyakarta : UPP AMP YKPN.

Pasolong, Harbani, 2007, Teori Administrasi Publik, Alfabeta, Bandung.

Prawirosentono, Suyadi. 2008. MSDM “Kebijakan Kinerja Karyawan” BPFE: Yogyakarta. 
Ronald O'reilly. 2003. Manajemen Sumber Daya Manusia. Prestasi Pustaka : Jakarta.

Sugiyono, 2013, Metodelogi Penelitian Kuantitatif, Kualitatif Dan R\&D. (Bandung: ALFABETA) Sondang P. Siagian, 2014. Manajemen Sumber Daya Manusia, Jakarta: Bumi Aksara.

Steers, Richard M. (2014). Efektivitas Organisasi. (Terjemahan). Jakarta : Erlangga

Sinambela,Lijan Poltak.Dkk. 2011:5. Pelayanan Publik. Jakarta:Bumi Aksara Uha, Ismail Nawawi. 2015. Budaya Organisasi Kepemimpinan \& Kinerja. Jakarta: Kencana. 